\title{
Being and Care in Organisation and Management - A Heideggerian Interpretation of the Global Financial Crisis of 2008
}

\author{
Michela Betta, Robert Jones and James Latham
}

\begin{abstract}
We propose to understand the global financial crisis of 2008 as an historical event marked by public decisions, economic evaluations and ratings, and business practices driven by a sense of subjugation to powerful others, uncritical conformity to serendipitous rules, and a levelling down of all meaningful differences. The crisis has also revealed two important things: that the free-market economy has inherent problems highlighting the limits of (financial) business, and, consequently, that the business organisation is not as strong as is usually assumed. We reconstruct some of the most dramatic events of that time by using the narratives of two former Lehman Brothers insiders. We then provide an interpretation of that world by using Heidegger's notions of being and care. Our investigation uncovers persistent inauthentic relationships nourished by the public structure of the financial market, which, drawing on Heidegger, we call the they. In the financial market the what of the world becomes more important than authentic being and self. But a hitch-free switch to authenticity becomes possible through anxiety and the call of conscience.
\end{abstract}

\section{Introduction}

N THE WAKE OF THE economic crisis of 2008, also called the global financial crisis, the most striking element that kept surfacing was the notion that business failed to selfregulate. In October 2008 Alan Greenspan, the then Federal Reserve chairman, conceded at a congressional hearing that "he had relied too much on the self-correcting power of

(c) Reason in Practice Ltd., 2014 
free markets". ${ }^{1}$ He was not the only one. Perhaps the most extraordinary idea of the power of financial business was captured in the statement that the banking system was "too big to fail" ${ }^{2}$ which must be read as too strong to collapse. Especially after almost 20 years of uninterrupted growth, Western governments seemed to cultivate the idea of a strong business community, which allowed them to practically relinquish their responsibilities to monitor the system or to create tighter conditions for self-regulation. ${ }^{3}$ The idea behind total self-regulation is that business is strong enough to address its own problems. Such an assumption, however, was criticised by Schumpeter back in the $1920 \mathrm{~s}^{4}$, especially in his works on the "capitalist method". ${ }^{5}$ Although Schumpeter thought that, if left to work according to "its own logic" capitalism would only progress towards ever greater stability, he identified serious obstacles - inherent economic flaws leading to self-destruction and originating from a tendency of capitalism to outgrow "its own frame" and so contradict its own logic. Maynard Keynes' successor, Hyman Minsky, added weight to the notion of internal instability, arguing that behind any form of stability looms its alter-ego. ${ }^{6}$ This prompted calls for more market equilibrium, a magic concept very dear to many economists especially after the economic crash of 1929. The issue of stability and of the system undermining itself returned more powerfully in 2008, forcing some American economists to denounce "our failure to recognize the instability of the capitalist system". B But contemporary economists do not seem to be willing to go as far as Schumpeter in identifying the malaise within the economic system itself. Instead, they insist that the major regulatory responsibilities lie with the governments.

In this paper, we propose to take a closer look at the conditions that led to the global financial crisis. In the next two sections we will reconstruct some of the most dramatic events that preceded and accompanied the global financial crisis. Here we point to shortcomings on the part of government agencies and offices that failed to anticipate the crisis, and illustrate this with the demise of the financial institution Lehman Brothers using the

1 Hershey H Friedman \& Linda Weiser Friedman 'The Global Financial Crisis of 2008: What Went Wrong?' in: Robert W Kolb (ed) Lessons From the Financial Crisis - Causes, Consequences and our Economic Future pp 31-36 Hoboken, NJ, John Wiley \& Sons 2010.

2 Andrew Ross Sorkin Too Big to Fail - The Inside Story of How Wall Street and Washington Fought to Save the Financial System - And Themselves New York, Penguin 2009.

3 James K Galbraith 'The Roots of the Crisis and How to Bring it to a Close' in: Robert W Kolb (ed) Lessons From the Financial Crisis - Causes, Consequences and Our Economic Future pp 37-42 Hoboken, NJ, John Wiley \& Sons 2010.

4 Joseph A Schumpeter Capitalism, Socialism, and Democracy London, Allen \& Unwind 1943; Joseph A Schumpeter 'The Instability of Capitalism' in: Joseph A Schumpeter Essays on Entrepreneurs, Innovations, Business Cycles, and the Evolution of Capitalism Edited by R.V. Clemence. $7^{\text {th }}$ edition pp 47-72 New Brunswick and London, Transaction Publishers 2004.

5 Joseph A Schumpeter 'Capitalism in the postwar world' in: Joseph A Schumpeter Essays on Entrepreneurs, Innovations, Business Cycles, and the Evolution of Capitalism Edited by R.V. Clemence $7^{\text {th }}$ edition pp 175-188 New Brunswick and London, Transaction Publishers 2004.

$6 \quad$ Galbraith, op cit 2010 p 38.

$7 \quad$ ibid $\mathrm{p} 37$. 
narrative accounts of two Lehman insiders, Lawrence McDonald and Joseph Tibman. ${ }^{8}$ We then reconstruct how, in pursuing new and extravagant ways of making money, financial business became an unscrupulous enterprise supported by the three major American rating agencies. We then try to put these events into perspective by elaborating on the type of human agency at work within the financial sector of the 1990s and 2000s. To this purpose we draw on Heidegger and his notions of being and care ${ }^{9}$. We conclude by pointing to the necessity for business to understand that the market is a dispassionate reality: a neutral and indifferent public space that can support or undermine all or several of its own constitutive entities.

\section{The Limits of Business}

In this part of the text we take the somewhat unusual step of using autobiographical narratives to illustrate the events that marked the rise and fall of Lehman Brothers. According to Ford et al. ${ }^{10}$ autobiographical accounts of "personally salient and specific episodes or events are typically more accurate than recollections of more general and emotionally neutral experiences". And although we are aware that autobiographies might not always be accurate, or that they might selectively include and exclude events, or promote some personal ideology, we would argue that any such problems are outweighed by the advantages that this material offers, especially when it coheres around "a life in writing".

In 1999 the then American president Bill Clinton signed into law the new Financial Services Modernization Act (Gramm-Leach-Bliley Act). According to McDonald, a former Lehman Brothers broker, "in less than a decade, this act would be directly responsible for bringing the entire world to the brink of financial ruin". ${ }^{11}$ This was a decision with unprecedented effects because the new law overrode the Glass-Steagall Act of 1933 that prevented merchant banks merging with investment banks. McDonald has argued that such a decision was literally pushed through by people working in the then Department of Housing and Urban Development where the financial sector was reprimanded for not lending money to poor people especially of ethnic backgrounds. The discourse of equity reached its peak when banks were fined or reported for bad community engagement. "Mortgage officers inside the banks were forced to bend or break their own rules in order to achieve a good Community Reinvestment Act rating that would please the administration by demon-

8 Lawrence G McDonald Colossal Failure of Common Sense. The Inside Story of the Collapse of Lehman Brothers. With Patrick Robinson New York: Three Rivers Press 2009; Joseph Tibman The Murder of LEHMAN BROTHERS. An Insider's Look at the Global Meltdown New York, Brick Tower Press 2009.

9 Marin Heidegger Being and Time New York, Harper and Row 1962.

10 Eric W Ford, Jack Duncan, Arthur G Bedeian, Peter M Ginter, Matthew D Rousculp \& Alice M Adams 'Mitigating risks, visible hands, inevitable disasters, and soft variables: Management research that matters to managers' Academy of Management Executive 19 no 4 (2005) pp 24-38, p 26.

11 McDonald op cit 2009 p 7. 
strating generosity to underprivileged borrowers even if they might default. Easy mortgages were the invention of Bill Clinton's Democrats". ${ }^{2}$

The easy mortgages policy that followed led to the sub-prime crisis and the emergence of the practice of mortgage securitisation. This was also facilitated by the fact that the two main players in this extraordinary easy money bonanza, Freddie Mac and Fannie Mae, were "quasi-government mortgage giants"13 that enjoyed aaa/AAA rating from the three American rating agencies Moody's, Standard and Poor's, and Fitch. ${ }^{14}$ Tibman, who also was a Lehman Brothers employee, has suggested that such an exaggerated rating resulted from internal dysfunctional organisational processes ${ }^{15}$ inasmuch as "everybody robotically did what they always did" without properly checking what they were doing. Such habitual processes "indelibly tarnished the agencies' reputations" ${ }^{16}$ At that time there already existed a form of securitisation of bank loans that turned a debt into a bond ${ }^{17}$ and that experts considered a "primitive form of securitization". ${ }^{18}$ Major problems started to appear on the horizon when the primitive practice of bond creation was enriched by an explosive mixture called convertible bonds that allowed a bond holder to switch to shares.

In the late nineties, however, the securitised bonds extended to sub-prime mortgages that were handled like bond securitisation. Securitisation was nothing more than credit derivatives that transformed "a thousand mortgages into a bond with an attractive coupon of 7 or 8 percent" ${ }^{19}$ Concomitant with these developments, a chain of dramatic events would further highlight the inherent fragility of business and its organisations. In April 2001, Pacific Gas and Electric filed Chapter 11 bankruptcy with a total debt of $\$ 36$ billion, "the biggest bankruptcy in history to date". ${ }^{20}$ On 11 September 2001 one of the symbols of economic power was destroyed in an unprecedented terrorist attack that undermined the very existence of many firms. Just as if that attack had been a premonitory sign of the internal weakness of the American society and its business/financial institutions, a series of bad events followed: On 2 December 2001, Enron filed for bankruptcy with $\$ 65$ billion in non-payable debts. ${ }^{21}$ Further bankruptcies followed soon after: Global Crossing, Qwest, NTL, Adelphia Communication, and WorldCom. For Lehman Brothers conducting busi-

12 ibid p 4.

13 Tibman op cit 2009 p 55.

14 Moody's, Standard and Poor's, and Fitch are the only rating agencies recognised by the free market economy. They have no competitors and their ratings are usually considered by governments and business as incontestable. Despite this, some market observers are starting to question their objectivity and reliability, especially after the global financial crisis of 2008 and the persisting banking problems within the European Union.

15 Tibman op cit 2009p 65.

16 ibid p 63.

$17 \quad$ McDonald op cit 2009 p 37.

18 ibid p 38.

19 ibid p 74.

20 ibid p 68.

21 ibid p 70. 
ness became a matter of survival: "Following the events of $9 / 11$, we set about the task of building our business as if waging war". ${ }^{22}$

Nine days after the WorldCom collapse, the Sarbanes-Oxley Act was passed into law on 30 July 2002. The Act forced CEOs and CFOs to sign statements that all debts had been disclosed and to personally guarantee the validity of both the financial and the company's assets. "By the end of 2002, Wall Street was predictably in trouble ... its lucrative fee engines, the huge income generated from major bond issues, had ground to a halt". ${ }^{23}$ It was then that a new "fee generating machine" was invented by the Wall Street elite called securitisation of credit derivatives. "One of the unintended consequences of Sarbanes-Oxley was the driving up of the corporate bond market. Securitization of credit derivatives helped fill the revenue gap". ${ }^{24}$ At the same time as these events and problems were occurring, the Federal Bank cut rates from $6 \%$ in 2000 to $1 \%$ in 2003. "Thus began one of the greatest consumer-borrowing bonanzas since the $1920 \mathrm{~s}$. ${ }^{25}$ Easy mortgages for those who in the past would not have qualified for a bank loan, out-of-control high levels of borrowing, and the cutting of the cost of money through low interest rates were the results of socio-political decisions that, in the end, threatened economic rationality. Never in the history of money and credit had social considerations played such a strong role in economic matters.

There are two main issues related to this reconstruction. First, social and political imperatives were directed towards business with the purpose of solving wider problems of a socio-political nature. For example, the Administration could have built social housing in order to help low income people to access property. Second, the business community was caught in an accumulation habit, unmonitored by Treasury, the Federal Reserve, or other agencies supposed to regulate the sector. The subsequent Bush administration increased the level of deregulation inasmuch as "not only rules but even enforcement grew lax. In fact, under Bush, enforcement became less vigorous by design" 26 and finally became "moribund". ${ }^{27}$ This reflected a violation of fundamental rules within economic reason itself.

Before the passing of the Gramm-Leach-Bliley Act of 1999 mortgages for commercial banks were "forbidden fruit" 28 but once the change came into being and mortgage securitisation became a practice "the lenders originating loans sold to Freddie and Fannie no longer had any particular incentive to maintain their traditional high credit risk standards, since the risk was no longer on their books but had been passed to Fannie and Freddie". ${ }^{29}$ At the same time, legislative decisions driven by political utilitarianism allowed the investment system to breach its own limits (the overriding of the Glass-Steagall Act 1933 is a prominent example).

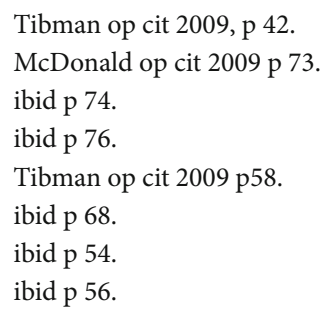


By limits we mean inherent conditions that once unsettled can undermine the very logic underpinning the capitalist / free market structure. In the present case, for example, an alteration of the level of risks perception, and a highly superficial calculation and classification of risks, both directly undermined the financial business practice of that time, leaving it exposed to volition and speculation which is what the Glass-Steagall Act had prevented since 1933. Hence, we speak of operational limits with ethical and social repercussions. By asking whether capitalism is stable in itself, Schumpeter points to the many conditions determining capitalism / free market economy and which, in his view, are different from ethical, social, and political conditions inasmuch as the economic stability can contribute to the other stabilities without, however, being "synonymous with them" or "implying them". ${ }^{30}$ This could also mean that, in the same way as it can contribute to their stability, it can also contribute to their instability.

\section{Inauthentic Relationships}

In this part of the text, we describe the context in which the entrepreneurial organisation Lehman Brothers created new ways of earning money and increasing profit (called securitisation) within sub-prime mortgages in the United States. Such mortgages were sold to borrowers with low credit ratings who normally would not have qualified for a conventional mortgage. It started with the entrepreneurial creation of a collateralised debt obligation (CDO) - a new technology designed and perfected in Wall Street's investment banks such as Lehman Brothers and Merrill Lynch. "The process began in the offices of large US mortgage brokers, particularly in California, Florida, and Nevada, where the prospect of a fast buck has never antagonized the natives". ${ }^{31}$ This was the era of the rise of shadow banks institutions that provided the funds to borrowers but that had no depositors themselves. They had to borrow the money from existing and operating visible banks before they could lend it out. The shadow banks then quickly sold on the mortgages to the Wall Street banks. For example, shadow banks sold 1,000 mortgages at \$300,000 each, which generated a total debt of $\$ 300$ million.

This was fully collateralised by the property deeds. The housing market was booming, borrowers paid their monthly mortgages promptly, and house prices were escalating. Therefore, the level of risk was considered to be very low or close to zero. Lehman bought the loans for $\$ 300 \mathrm{M}$, created a bond by securitising the debt, and sold them to investors, who would "sit back and collect a share of the massive monthly repayments from the homeowners". ${ }^{32}$ Mortgages sold to sub-prime borrowers were adjustable upwards: the interest rate jumped dramatically to $9-10 \%$ after the first few years, during which a

$30 \quad$ Schumpeter op cit 2004 pp 175-188.

31 McDonald op cit 2009 p 107.

32 ibid. 
low honeymoon rate of $2 \%$ was offered. Salespeople did not see this as a problem. The US housing market was rising at an average of $10 \%$ per annum. After one year a $\$ 300,000$ house would be worth $\$ 330,000$. Extra repayments would be covered by the equity in the house. "That's the way it worked - the US housing market had never dropped more than 5\% in any year since the Great Depression". ${ }^{33}$ As a result, the bond was solid and attracted the highest possible ratings - and yet bond meant "debt, nothing more" ${ }^{\text {. }}$

It was a system where taking care was embedded in particular interests - the original salespeople of the mortgages out in the field (who received large commissions), the shadow banks (which quickly passed on the debts to the Wall Street banks at large profits), and the investment banks (that received huge profits from the CDOs). The people who eventually ended up with the CDOs did not really understand what they had invested in. As soon as one link in the chain passed the debt onto another party "the problem was no longer theirs". ${ }^{35}$ The vast distance between the house owner and the eventual owner of the debt acted to dilute the veracity of any complaints that may have emerged down the line. The creators of the system were the mortgage and property people located on the upper floors of the Lehman Brothers building. Because of their status, their practices were beyond question.

According to MacDonald, nobody "dare[d] mention even a semblance of doubt, not to anyone"; to do so would have been "tantamount to high treason". ${ }^{36}$ Instead, it would have been better for Lehman Brothers to trust their critics, the internal opponents who resisted the trends of the money machine and who, according to MacDonald and Tibman, were numerous and included the most accomplished of Lehman's senior traders and investors. But this would have required an act of humility on the part of the reclusive CEO Dick Fuld and his entourage; it would have required an active duty of care towards the firm, the employees, and the stakeholders. More independence and authentic relationships could have saved the organisation.

This case study about the global financial crisis has highlighted types of risks that financial institutions themselves cannot control and that are related to the market and its tendency to outgrow itself. The organisation is the prominent place where actions and decisions occur and where human agency is embodied in practices and relationships involving others. But it is also the place where businesses expose themselves to risks, some of which are so big that they can ultimately undermine the existence of the organisations that carry them. It is to this place, the organisation, that we now turn to elaborate on the type of being acting in it.

\footnotetext{
33 McDonald op cit 2009 p 110.

34 ibid p 71.

35 ibid p 108.

36 ibid p 114.
} 
Being and Care in Organisation and Management - A Heideggerian Interpretation

\section{Being and Care in the Organisation}

That organisations are not easy places to live and work in had already become apparent in the $1920 \mathrm{~s}^{37}$, and increasingly in the $1950 \mathrm{~s}^{38}$ and $1960 \mathrm{~s}^{39}$ when business organisations were studied from the perspective of their strengths and power to destroy social and cultural values. Faced with never-ending issues and problems in business, scholars in the businessethics field have been designing and redesigning increasingly complex and complicated rules, codes, methods, and methodologies for the past eighty or so years with the intent of controlling organisational behaviour within the business sector. By so doing they have conceptualised organisations as too strong to be tamed by regulations, whether external or self-imposed. ${ }^{40}$ Lately, however, an increasing number of scholars have paid more attention to business as a social practice determined by ethical limits ${ }^{41}$, questioning the usual perception of business and its organisations as an independent entity within socio-market conditions. In fact, it is worth remembering that the corporate collapses of the past 15-20 years clearly point to some systemic failures concerning not just businesses. As shown in the case study above, these collapses have also involved social institutions and political organisations (governmental scrutiny agencies) highlighting a high level of interdependence between business and society.

Hence, it seems that, although organisational life has been under scrutiny for the past 80 years, neither mainstream business ethics literature nor its more critical stream have provided a sustained analysis of what it means to be within business organisations and their management practices. By way of being schematic, we would suggest that there are three major schools of thought cohering around the business organisation. First, there are those who want to strengthen the organisation at the expense of the individual by insisting

37 W B Donham 'The Social Significance of Business' Harvard Business Review 4 no 4 (1927) pp 406-419.

38 Howard Rothman Bowen Social Responsibility of the Businessman New York, Harper and Row 1953.

39 Raymond C Baumhard 'How Ethical Are Businessmen?' Harvard Business Review 39 no 4 (1961) pp 156-76.

40 Andrew Crane, David Knights \& Ken Starkey 'The Conditions of our Freedom: Foucault, Organization, and Ethics’ Business Ethics Quarterly 18 no 3 (2008) pp 299-320; Campbell Jones 'As if Business Ethics Were Possible, Within Such Limits' Organization 10 no 2 (2003) pp 223-248; Linda Klebe Treviño 'Ethical Decision Making in Organizations: A Person-situation Interactionist Model' Academy of Management Review 11 no 3 (1986) pp 601-617; Ben Wempe 'In defense of a Self-disciplined, Domain-specific Social Contract Theory of Business Ethics' Business Ethics Quarterly 15 no 1 (2005) pp 113-135.

41 John Dobson 'Alasdair Macintyre's Aristotelian Business Ethics: A Critique' Journal of Business Ethics 86 (2008) pp 43-50; Alasdair MacIntyre After virtue Notre Dame, University of Notre Dame Press 1984; Roudan Shao, Karl Aquino \& Dan Freeman 'Beyond Moral Reasoning: A Review of Moral Identity Research and its Implications for Business Ethics' Business Ethics Quarterly 18 no 4 (2008) pp 513-540; Jason Stansbury 'Reasoned Moral Agreement: Applying Discourse Ethics Within Organizations’ Business Ethics Quarterly 19 no 1 (2009) pp 3356. 
on collective agents, collective decision making processes, and systems of shared values. ${ }^{42}$ Second, there are those who have a scientific approach to organisation and nourish a wish to develop models, or design theories, that could help predict problems ${ }^{43}$ or intentions ${ }^{44}$ within the business field. Third, there are those who see great powers at work within organisations and who, by insisting on (totalising) discourses, tend to underestimate the strengths of human agency and the productive effects of social practices. ${ }^{45}$

In this paper, we would like to position ourselves differently, and approach organisations from the perspective of being rather than ethics or power. To achieve our objective we introduce a discussion of being and care in organisations. More precisely, we are interested in elaborating on the type of being involved in the financial crisis of 2008 . We propose a Heideggerian reading of the crisis by focusing on Heidegger's major work Being and Time (1962). Heidegger was driven by two questions: What do we mean by being? and How does the being of human agency (which he calls Dasein) disclose itself in everydayness? ${ }^{46}$. These two issues are, in turn, embedded in his critique, namely that we seem to assume far too much when we speak of entities in the world because in doing so we tend to split the world

42 David De Cremer, David Mayer \& Marshall Schminke 'On Understanding Ethical Behavior and Decision Making: A Behavioral Ethics Approach’ Business Ethics Quarterly 20 no 1 (2010) pp 1-6; Jason Stansbury 'Reasoned Moral Agreement: Applying Discourse Ethics Within Organizations' Business Ethics Quarterly 19 no 1 (2009) pp 33-56; Linda Klebe Treviño, Gary R Weaver \& Scott J Reynolds 'Behavioral Ethics in Organizations: A Review' Journal of Management 32 no 6 (2006) pp 951-990; Gary R Weaver 'Virtue in Organizations: Moral Identity as a Foundation for Moral Agency' Organization Studies 27 no 3 (2006) pp 41-368; Gary G Weaver \& Linda Klebe Treviño 'Normative and Empirical Business Ethics: Separation, Marriage of Convenience, or Marriage of Necessity?' Business Ethics Quarterly 4 no 2 (1994) pp 129-144.

43 De Cremer et al. op cit 2010; Treviño op cit 1986; Linda Klebe Treviño \& Gary R Weaver 'Business ETHICS/ BUSINESS Ethics: One Field or Two?' Business Ethics Quarterly 4 no 2 (1994) pp 113-128; Gary R Weaver \& Linda Klebe Treviño 'Compliance and Values Oriented Ethics Programs: Influences on Employees' Attitudes and Behaviour’ Business Ethics Quarterly 9 no 2 (1999) pp 315-335.

44 Kenneth Bass, Tim Barnett \& Gene Brown 'Individual Difference Variables, Ethical Judgements, and Ethical Behavioural Intentions' Business Ethics Quarterly 9 no 2 (1999) pp 183-205.

45 Stewart Clegg \& Mark Haugaard The SAGE Handbook of Power. London, SAGE 2009; David Courpasson \& Françoise Dany 'Cultures of Resistance in the Workplace' in: Stewart Clegg \& Mark Haugaard (eds) The SAGE Handbook of Power pp 332-347 London, SAGE (2009); Crane et al., op cit, 2008; Peter Fleming \& Andre Spicer Contesting the Corporation: Struggle, Power, and Resistance in Organizations Cambridge, Cambridge University Press 2007; Susan Halford \& Pauline Leonard 'Place, Space and Time: Contextualizing Workplace Subjectivities' Organization Studies 27 no 5 (2005) pp 657-676; David Knights 'Subjectivity, Power and the Labour Process' in: David Knights D \& Hugh Willmott (eds) Labour Process Theory pp 297-335 London, Macmillan 1990; David Knights \& Glenn Morgan 'Corporate Strategy, Organizations, and Subjectivity: A Critique' Organization Studies 12 no 2 (1991) pp 251-273; Tim Newton 'From Freemason to the Employee: Organization, History and Subjectivity' Organization Studies 25 no 8 (2004) pp 1363-1387; Carl Rhodes 'Reading and Writing Organizational Lives' Organization 7 no 1 (2000) pp 7-29.

46 In translating Dasein with human agency we align ourselves with one of Heidegger's contemporary interpreters: Michael Wheeler Reconstructing the Cognitive World Cambridge, Mass and London, The MIT Press 2005, p 122. Another equally prominent interpreter also uses the notion of 'way of being' or 'way of acting': Herbert L Dreyfus Being-in-the-world. A commentary on Heidegger's Being and Time, Division I Cambridge, Mass, MIT Press (1993 $4^{\text {th }}$ edition), p 14 and 16. 
between self-regulating and deliberating subjects guided by consciousness and self-awareness on the one hand, and passive objects on the other.

According to this understanding, human agency would have to mediate between the two, although mainly in favour of the subject who is perceived as superior by dint of being furnished with an independent will. Heidegger argues that such an understanding of being in the world is influenced by the metaphysical notion that being is a universal category that does not need further explanation. Instead, he calls it the "darkest of all" ${ }^{47}$ Practically, Heidegger proposes to reflect about a more primitive form of intentionality that does not stand on the notion of a self-sufficient individual/subject interpreting the world through mental/cognitive processes. It is in the world that human agency is daily confronted with the necessity to cope with given social conditions and practices. This continuous necessity to cope within given "cultures" is what characterises being-in-the-world as a practical, that is existential, condition within which human agency is first and foremost being-in. Coping happens because human beings are usually aware of their condition. Such coping becomes a problem only when our social habits lose their ability to respond to social practices, that is, when coping is no longer "hitch-free". ${ }^{8}$ It is then that awareness turns into self-awareness. Confronted with a problem, Dasein becomes aware of the issues that under normal condition are so transparent that they do not require any mental elaboration.

Heidegger argues that this aware, but not self-aware, being must be made explicit without recurring to phenomena that are usually described as will, wish, addiction, urge, and so forth. The way by which it can be made explicit is through care. Dasein cares about itself, which is shown in the fact that being is an issue to it. But Dasein's own understanding of being "is not a belief system implicit in the minds of individual subjects" comportment towards oneself driven by the question of what it means to be this Dasein.

The idea is that, by being preoccupied with oneself, Dasein interprets its own being and the being of those with whom it shares the world. This hermeneutic attitude of self-interpretation affects the way human agency responds to social practices and the reality of the world. Human agency cares about the world and its possibilities; it is open to it and takes an interest in others. Hence, will, desire, wish, and so forth all derive from care and not vice versa. ${ }^{50}$ Heideggerian care (Sorge) is an ontological structural concept, and so it does not refer to tribulation, melancholy, or the care of life, or to more positive affections such as gaiety or freedom from care ${ }^{51}$. The care we are dealing with is related to concern towards one's being and the being of the world.

Care represents the basic structure of Dasein: it is a way by which Dasein makes its own being an issue to itself. Hence, care is used by Heidegger in a rather technical way to express

$47 \quad$ Heidegger, op cit 1962 p 23.

48 See on the this John Dewey Human Nature and Conduct. An Introduction to Social Psychology London, Allen \& Unwin 1922, p 178.

49 Dreyfus op cit 1993 p 70.

$50 \quad$ Heidegger op cit 1962 p 227.

51 ibid p 84. 
how human agency responds to the world and copes with its practices, cultures, and structures. More importantly, care is the condition for being-in as being-with-others. However, this being open to the world and being-with entail some great risks because in everyday life human agency becomes "absorbed in the world of concern". ${ }^{52}$ Such concern characterises an undifferentiated character of Dasein that Heidegger calls "averageness" in everydayness.

Heidegger then suggests that, in order to understand Dasein's mode of being closest to us it becomes necessary to analyse Dasein in its average everydayness; and the world of everydayness closest to us is the environment, while the environment that is closest to us is the "work-world of the craftsman" where Dasein encounters the social practices and cultures that require "masterful" and "skillful coping"; 53 but in the work-world Dasein also encounters the others "for whom the 'work' is destined". ${ }^{54}$ It is here that being-in-the-world becomes being-with others. However, by others it is not to be understood "everyone else but me". The others "are rather those from whom, for the most part, one does not distinguish oneself - those among whom one is too". ${ }^{55}$

The work-world is the environment of everydayness and publicness where Dasein encounters others existentially, namely as "what they are" because "they are what they do". And in this encounter care strongly expresses a "constant care as to the way one differs from them". ${ }^{56}$ This differentiation becomes an urgency because Dasein does not encounter definite others, inasmuch as one belongs to these others and continually "enhances" their power. Who is then this other that is encountered by human agency? Heidegger states that "the who is not this one, not that one, not oneself, not some people, and not the sum of them. The who is the neuter, the they (das Man)". Such indefinite reality called the they "prescribes the kind of being of everydayness". In everydayness being can be the they-self or the authentic self: two simple modes of being that Heidegger describes as authenticity or inauthenticity.

These two modes of being are not mutually exclusive ${ }^{57}$; indeed they are both given realities for the human being resulting from a choice. Inauthenticity does not mean a "less" being or any "lower degree" of being. It simply is a mode of being that Dasein experiences when "busy, when excited, when interested, when ready for enjoyment". This tells us that in Heidegger's design authenticity and inauthenticity are not to be perceived as moral values that one is self-aware of and that one aims to obtain or to escape. Rather, it is through care that a sense of authenticity becomes a question of urgency for Dasein. In the they-world Dasein is rather concerned with the what of the world and so its care becomes inauthentic because it focuses on things that affect its being in a mundane way. In the they world Dasein

$52 \quad$ ibid p 163.

53 Dreyfus, op cit 1993 p 67. Others have proposed the term 'practical coping': Robert Chia \& Robin Holt 'Strategy as Practical Coping: A Heideggerian Perspective’ Organization Studies 27 no 5 (2009) p 635-655.

$54 \quad$ Heidegger op cit 1962 p 153.

55 ibid p 154.

56 The following citations refer to pp 163-167.

57 Heidegger op cit 1962 pp 68-69. 
loses its way and fails to stand by "one's Self"; in other words it falls into the world. In the they the self is dispersed and must find itself.

How can this inauthentic being switch back to authentic being? It is through anxiety that, according to Heidegger, the they self is undermined because anxiety "individualizes" bringing Dasein back from its falling. ${ }^{58}$ But Dasein needs another element to return to authenticity that Heidegger describes as the call of conscience: "Conscience summons Dasein's self from its lostness in the "they"'. The call of conscience is not a trial of the Self; rather it summons Dasein to its "ownmost potentiality-for-Being-its-Self". ${ }^{59}$

\section{The Financial Market as the They}

We propose to describe the financial market as the they because "the more openly it behaves, the harder it is to grasp and the slier it is". ${ }^{60}$ Heidegger states that the they is the "realest subject of everydayness" and yet it is not a "universal subject"; and although it is not visible like a thing, to decree that it is nothing would be a premature decision. The they is the public domain that constantly "accommodates" Dasein because it belongs to Dasein's "positive constitution". This, however, does not mean that it is a totality inasmuch as "the extent to which its dominion becomes compelling and explicit may change in the course of history". The being of the they discloses itself as distantiality (subjection to others), averageness (conformity to norms) and levelling down (suppression of meaningful difference) as the triple structure of publicness. Heidegger understands the being of publicness as "insensitive to every difference of level and genuineness" which is why it never "gets to the heart of the matter". ${ }^{61}$

Throughout his cathartic recollection McDonald has articulated a process where distantiality, averageness, and levelling down of meaningful differences form his everydayness. The crisis affected him in a particular way, turning him away from the they-self towards a more authentic self that now cares about being-in-the-world. Speaking about the crisis he acknowledges that:

It changed me. It stripped away all the careless glances at stock charts I have lived with all my life. The ramifications of those charts have a different meaning now. Where once I stared at zigzagging lines, and just thought, Up, down, win, lose, profit, crash, problem, solution, long, short, buy, sell, now I see mostly people. Because every movement, up or down, has a meaning. I see it because I've been there. Every fraction of every inch of those financial graphs represents hope or fear, confidence or dread, triumph or ruin, celebration or sorrow. There's nothing quite like total calamity to focus the mind. ${ }^{62}$

$58 \quad$ ibid p 235.

59 ibid pp 318-319; emphasis in original text.

60 ibid pp 165-166.

61 ibid pp 166-167.

62 McDonald op cit 2009, p 339, italics in original. 
The falling into the they-world is stopped by a sense of anxiety that refocuses the attention on meaningful being rather than the whats affecting it. Once anxiety confronts Dasein with its inauthentic life the call of conscience makes it possible to summon the self to its ownmost possibilities for being authentic.

Reflecting on the 9/11 terrorist attack, Tibman, too, dwells on how it affected him and the others around him.

Events had altered my sensibility. The profession that I often think chose me was no longer just a job. Within a day of the assault, when a number of offices were shorn off our building, I found I cared far more that I had realized about my colleagues. My real life had always been outside the office. After 9/11, what mattered was the plain fact that I and the people I knew at Lehman had survived... We were more like a family that needed to remain connected. People I had never called at home, I called. Others called me. ${ }^{63}$

Here Tibman experiences for the first time what it means to be in-the-world as a manifestation of care and concern for authenticity. As Heidegger argues, existing is always factical, existentiality is essentially determined by facticity. ${ }^{64}$

\section{Implications for Organisation and Management}

What are the implications of our analysis for organisation and management? Organisations are examples of work-worlds where Dasein's being is exposed to social practices that it copes with in its everyday interactions with others and things. Here Dasein articulates its modes of being by responding to what is there. In the early 1980s, Knights and Morgan ${ }^{65}$ describe the interdependence of agency and constraint within organisational and managerial practices as constitutive of action insofar as one can always "do otherwise". This means that both are modes of being that we choose. Drawing on this idea, we understand being within business organisations as both constrained by entrepreneurial pressure to be innovative and competitive on the one hand and driven by a sense of care towards oneself and others on the other. To exemplify this relationship we highlight three major points that also summarise our work.

63 Tibman op cit 2009, p 39.

64 Heidegger op cit 1962 p 236.

65 Op cit 1981 p 254. 
Being and Care in Organisation and Management - A Heideggerian Interpretation

\section{Care Rather and the They}

We have explained above that Dasein, or human agency, starts with the question of being which becomes central to it. This question reveals a specific form of care towards entities in-the-world. Care is a comportment towards oneself that is exposed to the they, the publicness of everyday life, and that we have compared to the financial market. The central social practice of the market is the business activity that involves the work-world where human agency encounters others and is part of the they. What kind of being is the being of business? Referring to the they, or publicness, Heidegger makes a very important point: this social practice is driven by subjugation to others, conformity to norms, and levelling down of all meaningful differences.

The story of Lehman Brothers clearly reveals this structure: people were incapable of opposing the reprehensible financial activities and investments that they saw taking place (subjugation to others); there was a general conformity to serendipitous rules that many experienced traders considered to be a violation of good practices (averageness through conformity to rules); and, finally, unchecked financial and banking practices, investments, and profits revealed how little attention was paid to quality and professional standards (the levelling down of all meaningful differences). In his reflection about how Lehman Brothers collapsed, Tibman came to the conclusion that the lack of resistance against the power of those who were in charge had deleterious consequences. "Opposition to the build-up was discouraged" and those who opposed the emerging toxic practices "quickly disappeared from the firm or woke up next day in smaller, windowless offices". ${ }^{66}$ Difference was understood only in terms of competition. "I can honestly say that we played the crazed investment banking game a whole lot cleaner". Within Lehman "the culture was aggressive, not savage"' ${ }^{67}$

\section{Authenticity and Inauthenticity as Daseins' Being in Everydayness}

Care did exist within Lehman Brothers but it was exercised as care towards oneself as part of the business rather than as part of humanity. Other-care existed too, but was understood in terms of sharing accumulated wealth, a practice in which the ontological unity of self and being was not given insofar as being was not an issue to the agent. Those experiences were not inscribed in an authentic learning process, which is why Lehman collapsed in a powerful game where, to use a metaphorical expression, stepping outside one's own limits can cause death. A dead being will not be able to defend itself. "The sad confluence of trespasses and faulty industry and regulatory architecture that serendipitously came together, as neatly as a well orchestrated conspiracy, slitting the firm's throat and left it for dead, shall be forgotten"; what remains is a superficial story about "avarice on Wall street". ${ }^{68}$ These

66 Tibman op cit 2009 p 51.

67 Tibman op cit 2009 p 45.

68 Tibman op cit 2009 p 225. 
people knew that there were limits but they could not live according to them. This is a strong reminder that knowledge of/about things, the know-what, does not necessarily imply "know-how". ${ }^{9}$

Authenticity and inauthenticity are modes of being that we take on in everydayness in order to cope with the things that are just there or the issues and entities with which we conduct our lives. The they of the financial market is the place where being is taken over by issues related to making-money, increasing profit, buying and selling, and so forth - all entities that cohere around the what of social life. Heidegger seems to suggest that it is in the nature of everydayness to be neutral and indifferent to difference; in other words, social practices are what they are and so is the market which can always undermine itself or some parts of itself due to an innate tendency to outgrow its own space. The neuter they is neither benign nor malign - it is just what it is within the reality of everydayness. How we cope with it, whether authentically or inauthentically, becomes an existential issue for Dasein.

\section{Being and Care Free Human Agency from the Heavy Legacy of the Subject and Subjectivity}

If the they produces an inauthentic self who is absorbed in the they-world to the extent that being loses sight of meaningful differences, the question arises as to how Dasein can free itself from the effects of the they. In their discussion of the meaning of resistance within managerial practices Knights ${ }^{70}$ and Knights and Morgan $^{71}$ target what we, drawing on Heidegger, have called the they. But then these authors seem to suggest that employees are transformed into subjects and resistance comes from the wish to refuse the subjectivities imposed on them. We wonder whether we should not change the perspective and argue that human beings do not fight against their captivity because they want to be free, or because they have a will and desire to be free; rather it is because they are primordially and ontologically free that they can fight against those who keep them in chains (subjectivity). To do so Dasein must first reflect on its own being by making it an issue to itself. In other words, it needs ontological care.

\section{Conclusions}

Where does this leave the organisation and its managerial practices? Knights and Morgan lament that managerial strategy constitutes the problems that it claims to solve. ${ }^{72}$ Within the they world the whats require a circular logic of creation, expansion, and destruction/

Dewey op cit 1922 p 177-178.

Knights, op cit 1990.

Knights and Morgan op cit 1991.

ibid p 267. 
collapse. On the other hand, Rehn and Taalas ${ }^{73}$ suggest that management is more than "merely problem solving" as it involves emotions, hopes, visions, and motivations. In fact, Dasein experiences these affections in-the-world as resulting from care and making being an issue to oneself. It is through care, as explained from a Heideggerian perspective, that freedom acquires an ontological meaning embedded in the existential relationship between being and others. Ontological being needs the existential experience of everyday life to disclose itself, but it needs care in order to feel oneself as ontologically free. Care becomes central as soon as being becomes an issue to human agency. Making oneself an issue can take many forms ${ }^{74}$ within everydayness. But there is only one way through which we can learn how to question our being, how to become an issue to ourselves, and this is through an authentic relationship between Dasein, as human agency, and care towards oneself and the other in-the-world.

\section{Dr Michela Betta}

Michela Betta is a teacher, researcher, theorist, and writer. She studied philosophy and social sciences in Milan and Frankfurt, and completed her doctorate at the Johann Wolfgang Goethe University of Frankfurt. She is currently concerned with questions pertaining to the meaning, purpose, and scope of critical approaches to organisation, management and leadership, ethical theory, phenomenology, literary production, and dissemination of scientific knowledge. She has published on a variety of topics in scholarly journals and books embedded in her research interests. Michela has also published three collections of short stories with the intention of disseminating theoretical knowledge through literary media. She writes in three languages (Italian, English, and German).

\section{PROFESSOR ROBERT JONES}

Robert Jones is a specialist in the fields of human resource management, leadership, and organisational change. He has published three books and 49 refereed journal articles in 32 different journals, including Organization Studies, Public Administration, and International Journal of Human Resource Management.

\section{DR JAMES LATHAM}

James Latham began his working career as an apprentice in industry. In 1980, he changed his career and moved into academia where he has remained for over thirty years. During this period James has been an active researcher and teacher in human resource management and organisation studies, with a number of publications to his name. He also has spent some time as a consultant with private and public institutions.

73 Alf Rehn \& Saara Taalas 'On Wittgenstein and Management at Rest: Prolegomena to a Philosophy of Problems' Philosophy of Management 7 no 2 (2008), pp 47-54, p 48.

$74 \quad$ Dreyfus op cit p 238. 